\title{
A REVIEW OF THE AUSTRALIAN TUN SHELLS
}

BY

Charles Hedlex, Assistant Curator, Australian Museum.

\section{(Plates xxxix-xliv.)}

For a century Lamarck's name of "Dolium" " dating from 1801 has been employed for the Tun shells. But Mörch² pointed out that Tonnu of Brunnich, proposed in 1772, to say nothing of c'ulus, Bolten, introduced in 1798 , had precedence and this improved nomenclature is now generally adopted.

Tun shells are among the largest of Gasteropods, the huge "Beerbarrel" from New South Wales is now recorded with a capacity of four and a quarter pints and a length of nearly ten inches. But this size is exceeded by that of a giant from Sicily, mentioned by Philippi ${ }^{3}$, which had a length of eleven inches.

For various reasons, not much critical examination has been bestowed on the Tun Shells. Specimens do not often occur on the beaches, the bulk of some is inconvenient for ordinary collections and yet their wide range of variation demands a large series for satisfactory study. None have yet been recorded from the coasts of Tasmania or Victoria, though this deficiency will probably be remedied when the deeper waters of those States are searched. The appearance of an unknown species from this coast has induced the writer to examine the series in the Australian Museum and to offer the following review.

In an analysis of the Australian species, the tropical ' $T$ '. perdia, for which Montfort ${ }^{4}$ created a genus, Perdrix, may be distinguished by its slender form and with it may be grouped $T$. canuliculata. The remainder may be divided into those with a toothed and reflected lip, viz.:- I'. costuta, Menke, T. parvula, Tapparone Canefri, and T. sulcosa, Born, and those with a sharp simple lip:-T. ampullacea, Philippi, 'T. cerevisina, Hedley, T. cumingii, Reeve, 'T'. picta, Schepman, T. tetracotula, Hedley, and 'T'. variegata, Lamarck. In the latter group there is a colour scheme which oscillates from spots to bands.

In 1847, when in H.M.S. "Rattlesnake," the veteran collector John MacGillivray gathered a larval mollusc a little to the south of Cape Byron, New South Wales, which he described ${ }^{5}$ in a letter to his friend, Prof. E. Forbes. This was afterwards called Macgillivrayia pelagicu ${ }^{6}$, and types of it are preserved in the Royal Scottish Museum, Edinburgh. Subsequently Dr. Paul Fischer ${ }^{7}$ classified $M$. pelagica as a Dolinm. It would not be wise to attempt to identify this larval shell with any particular species of the genus. The admission ${ }^{8}$ of I'onna perdie to the fauna of New South Wales as a synonym of $\boldsymbol{M}$. pelagica, following $\mathrm{Dr}$.' Fischer is regretted.

\footnotetext{
1 Lamarck-Syst. Anim. sans Vert., 1801, p. 79.

Mörch_Malak. Blatt., xviii., 1871, p. 16.

Philippi-Moll. Siciliæ, i., 1836, p. 219.

Montfort-Conch. Syst., ii., 1810, p. 447.

MacGillivray-Ann. Mag. Nat. Hist. (2), ii., 1848, p. 31.

6 MacGillivray-Voy. Rattlesnake, i., p. 45, ii., 1852, p. 383, pl. iii., fig. 8.

7 Fischer-Journ. de Conch., xi., 1863, p. 149.

8 Hedley-Journ. Roy. Soc. N.S.Wales, li., 1918, p. M 68.
} 